\title{
Quotas as a Path to Parity: Challenges to Women's Participation in Politics
}

\author{
Ana Alice Alcântara Costa
}

Abstract The promise of democratic equality has not arrived for women. In all societies said to be democratic, women have had an arduous struggle and are still fighting for access to rights common to any male citizen, for example an equal salary for equal work, promotion opportunities, the right to physical integrity, and access to work. Gaining the right to vote and the right to run for office as elected representatives has not in practice meant the right to be elected under the same conditions as men (Petit 2007). In the immense majority of representative democracies, women are far from having won political equality.

The huge difficulty that women face in being elected places in check the democratic commitment of societies who claim to be democracies. It also raises questions about the gap between the normative discourse on equality that exists in the majority of constitutional texts, in which the formal inclusion of women is explicitly stated, and the realities of women's continued political exclusion. In this article, I reflect on the implications of debates about seeking parity of political representation as a means of achieving formal equality between women and men in the political arena, and the use of quotas as an instrument of achieving this.

\begin{abstract}
1 Democracy in question: perspectives on parity The demand for equality between men and women in every public body has been present in feminist discourse from its beginnings. Feminist movements took shape around arguments for equality, as a universal value, framed by an Enlightenment perspective that all human beings have the same rights, by virtue of being human. This perspective oriented the entire course of emancipationist feminism. It formed the basis for the struggle for suffrage and, in a broader sense, all of the demands for political, civil and labour rights, inspired by the belief that the recognition of equality would in itself be sufficient to put women on an equal footing with men in constructing a fairer and more democratic society. This same universalist perspective is also the basis supporting the dominant notions of democracy and citizenship in modern societies, under the aegis of the liberal model. Democracy is understood as a mode of social and political organisation that defends the same rights for all individuals, based on the equality of these individuals before the
\end{abstract}

law, as well as the impartiality of this law in its treatment of all citizens.

Recognition of the androcentrism of the social contract has led to the need to revisit and redefine old notions of citizenship and to seek the means to transform patriarchal democracies into more legitimate representative democracies. Equality has come to be constructed, in this concept, in terms of the achievement of a level of parity as part of a process of constructing a legitimate democracy. Proposing a new distribution of power between men and women, the demand for parity is configured as a political proposal, involving a transformation of constitutions and electoral laws. As such, Cobo argues:

Its aim is a profound modification of the existing power structure between genders in liberal democracies, which locates women in a situation of permanent discrimination (...) The notion of parity democracy arises from the contradiction between the increase in the 
number of women in many areas of social life and their absence from the spaces where laws are voted on and decisions taken which affect the whole of society and most particularly, the lives of women. (2005: 3)

The demand for parity brings into question the existing principle of equality and of democracy itself as a system of representation (Gonzáles 2007). Various theorists of democracy have indicated the inclusion of women as one of the minimum conditions that define the democratic character of a society. An example is Robert Dahl, who establishes as minimum conditions for the exercise of democracy: the existence of political parties and organisations of civil society with equal participation of men and women, with programmes and ideologies which are distinct from the dominant one; the acceptance of a political opposition, consisting of the rights of any individual or group to challenge or replace those in power through elections; the guarantee of freedom of expression and association; independence of the media; respect for human rights of citizens of both sexes, notably of minorities (1993: 29).

Norberto Bobbio follows the same route defining 'democracy as a way, a method, a set of rules of the game which establish how collective decisions should be taken but not which collective decisions should be taken' (2000: 427). Amongst the rules that he identifies as 'essential points', the following deserves to be highlighted:

[A]ll citizens who have reached adulthood, without distinction as to race, religion, economic condition or sex, must enjoy political rights, i.e. each of them must enjoy the right to express his or her own opinion or to choose the person who expresses it for him or her, even if these are rules strictly within the formal sphere. (2000: 427)

From a critical standpoint, Anne Phillips (1996) notes that a liberal democracy usually considers that a promise of equality and participation is sufficiently met by legislation for universal suffrage and with the possibility, which is equal for all individuals, to compete in elections, as if social and economic conditions were not also decisive in these processes. She calls attention to the fact that even in modern societies it is generally women who assume the responsibilities related to unpaid housework, reproduction, caring for the young, old and sick. These are responsibilities that, in practice, act as a powerful barrier to the political commitment and participation of women. On the other hand, the fact that the cultural construction of politics is fundamentally male contributes to keeping those women at a disadvantage, who, despite all of the difficulties, attempt to insert themselves into political processes, or de facto excludes them.

With a view to overcoming these obstacles to the political participation of women, Anne Phillips proposes three possible solutions:

1 a different sexual division of labour in production and reproduction, with equal sharing of the entire range of paid and unpaid work existing within society, which until now has been the almost exclusive responsibility of women;

2 a modification in the work situation of politicians so that they can create possibilities for participation of individuals with active parental responsibilities;

3 elimination of the prejudices of the 'gentlemen's club' type among the electorate itself or of those responsible for selecting candidates within parties, which is something requiring affirmative action measures in order to encourage the election of women (1996: 83).

The fact that feminists have directed their efforts more towards the implementation of the third solution in recent years, Phillips believes, demonstrates that they do not believe that there is much scope for changing the first two.

In my view, what has been taking place in recent years is a greater visibility of actions aimed at change within the context of the state. It is not that feminists have abandoned the first two solutions. Indeed, there continues to be constant questioning of the sexual division of labour, the unrelenting struggle to construct new ideologies and cultural standards, the fight for sexual and reproductive rights. But feminists' daily contestation of other manifestations of the patriarchy has not merited the same visibility as actions that entail a confrontation with the apparatus of the state. Notwithstanding this, creating mechanisms that can break the barriers of exclusion of women from formal power is an important path to accelerating or even 
promoting the necessary changes. The demand for parity within the context of formal politics has been in the direction of constructing and guaranteeing changes in women's lives and in the effective exercise of their citizenship. For this purpose, it is necessary to create conditions that make these transformations possible. The system of quotas is only one of these conditions.

As we have seen in the article in this IDS Bulletin by Julie Ballington, in only five countries with representative democracies do women attain important percentages of participation in power structures without the intervention of any type of affirmative action. Against this, the vast majority of countries until recently excluded women from power, even those in which a woman's right to vote had been established for more than half a century. The fundamental issue in this discussion is not to demonstrate that women can achieve power without the aid of quotas, but that in the majority of countries, women have required some kind of intervention that has made this access possible. This intervention may take distinct forms, intensities and achieve different degrees of success, and the experiences narrated here certainly demonstrate this diversity of possibilities.

The contributions to this IDS Bulletin illustrate different experiences of quotas in various countries on a path to changing practices, cultures and ideologies that still exclude women from the formal spheres of decision-making. These experiences permit an analysis of the different procedures for affirmative action, and demonstrate how social, cultural and political contexts may define paths and make possible achievements or defeats that interfere with the achieved results. We may draw a number of lessons from the experiences narrated here, which may contribute to the successful application of quotas:

- The existence of a constitutional set of clear and precise procedures, accessible to all women, is fundamental. The application of quotas as a policy adopted in isolation by an individual officeholder or political party without its establishment as a legal framework has created latitude for the abandonment of the policy when a government changes. This has been the case in Pakistan and Egypt.

- The need for a quota policy to consider a series of legal mechanisms for punishment and restriction of those who do not comply with the law. Brazil is one of the clearest examples of failure of a quota policy, specifically because it did not include mechanisms which guaranteed the mandatory nature of these;

- The electoral system is a fundamental mechanism for the success of quotas. Proportional systems tend to promote the political rise of women in an evident manner, in the same way as systems with closed lists and defined positions for women (alternation);

- The reserving of seats in spaces of representation has shown itself to be a highly positive way of increasing political participation. Rwanda is the best example of this policy.

- Public financing of campaigns as a mechanism capable of guaranteeing the participation of women in electoral processes;

- The system of quotas has shown itself to be much more efficient in its application to representative structures within a local context;

- The existence of a 'political will' on the part of officeholders and party leaders committed to expanding the representation of women;

- The existence of actions/policies supplementary to the system of quotas and which support women's pathways into politics, as is the case in Rwanda.

\section{Limits to the use of quotas}

The importance of the quota system in expanding the political participation of women in the decision-making spheres of formal power is a fact. At the same time, the instrument of quotas is in itself inadequate for transforming dominant political institutional designs. In the majority of countries, when quotas were established there was no deeper change in the electoral rules within hegemonic political contexts. The quota is only one route open to the entry of women, without transforming the political reality of the country.

It may be stated that there has been a certain trend in the majority of countries in which quotas were implemented towards significantly favouring the election of women with links to the hegemonic sectors. In general, women are elected who are linked to the dominant political groups, 
with more conservative perspectives, thus making use of the prerogatives of the quota system. The case of Costa Rica in this sense is exemplary. In the face of this trend, it is important to recognise that the increase in the number of women within representative structures does not signify the empowering of women as a collective subject or even the existence of a critical consciousness regarding their condition of subalternity or the guarantee of a mechanism for coping with the dominant patriarchal structures. Indeed, world history has recorded a significant number of women who ascended to power (some to the highest positions in their countries) and who faithfully followed the established rules. This is, however, not a ground for invalidating the system of quotas as an important mechanism for expanding the access of women to formal power, nor is it a ground for seeking to maintain the exclusion of women from power. Guaranteeing equal participation for women in the structures of power is merely a question of democracy, of guaranteeing democratic rights. Women have the right to occupy these spaces under equal conditions to those of men.

We cannot forget that the representative structures within the context of the state are essentially patriarchal. They operate, are structured and guided by a male, androcentric logic, in which women's practices, values and experiences do not find spaces for their affirmation (Pateman 1996). In occupying these spaces, and then being able to assert themselves politically, women see themselves forced by their circumstances to assimilate and fit into this model, or risk not being heard and being submerged. It is not without good reason that our militant action as feminists or as 'agents of the promotion of gender equality' has been in the direction of enabling women to act within this space. According to Drude Dahlerup (2003), an essential element of the effective implementation of quota systems needs to be engagement by women's organisations and others in building the capacity of women to act effectively in political office. We thus start from the principle that women do not know how to deal with power, meaning that men have a 'natural' aptitude for power. We are unaware of any international financing for the political training of men to act within representative democracies. On the contrary, the various training processes involving men, in particular, those linked to union action or to an area more to the left, are directed to training men in how to question this model of representation and hegemonic structures.

This would be a paradox of political participation of women, which both questions the representative structures of liberal democracy and with it, the framing of citizenship - with these structures identified as patriarchal, androcentric, based on a 'virile archetype' of the rights bearing subject - and at the same time, works to 'adjust' and 'fit' women to the male models dominant within these power structures. The feminist perspective has not succeeded in envisaging alternative or more challenging forms of parliamentary action. The rebellion demonstrated in the field of gender relations has not succeeded in going as far as formal power.

Despite this adaptation and apprenticeship in 'doing politics', in exercising power, women have not succeeded in advancing their proposals very far, even those of a more general character. It may be stated that a current practice in the various representative bodies in which women have not yet succeeded in reaching a significant percentage, is the complete rejection of their legislative proposals and initiatives. Within the Legislative Assembly of Bahia, in Brazil, a kind of steamroller operates which does not allow women's proposals to progress. They are simply blocked. This is a current practice in Latin America and probably in any other authority of formal power.

These are some of the challenges that remain to be confronted by women in the field of politics, and which represent genuine access barriers to power for women. Behind them is the need for changes in culture, traditional attitudes and transformations. Quotas are merely one route towards parity. 


\section{References}

Bobbio, Norberto (2000) General Theory of Politics. Political Philosophy and the Lessons of the Classics Rio de Janeiro

Cobo, Rosa, La Fragilidad de la Democracia. El Debate de la Paridad [The Fragility of Democracy: The Debate on Parity] www.mujeresenmarcha.org/ documentos/LA\%20FRAGILIDAD\%20DE\%20 LA\%20DEMOGRACIA.pdf (accessed 28 May 2008)

Dahl, Roberto (1993) La Democracia y sus Críticos, Barcelona: Paidós

Dahlerup, Drude (2003) 'Quotas are Changing the History of Women', texts presented at the conference, The Implementation of Quotas. African Experiences, Stockholm

Fraisse, Geneviève (2003) Los dos Gobiernos: La Família y la Ciudad [Those who Govern us: Family and the City], Madrid: Cátedra, Col.

Feminismos

Guerra, María José (2007) 'Democracia Paritaria e Inclusión. Reflexiones Feministas'
['Democracy, Partity and Inclusion. Feminist Reflections'], in Angela González and Maria del Pino Ruiz (eds), Democracia Paritária (Aportaciones Para un Debate), Barcelona: Alertes, SA

Pateman, Carole (1996) 'Críticas Feministas a la Dicotomia Publico/Privado' ['Feminist Critiques of the Public/Private Dichotomy'] in Carme Castelles (ed.), Perspectivas Feministas en Teoria Política [Feminist Perspectives on Political Theory] Barcelona: Paidós

Petit, Cristina Molina (2007) 'Democracia Paritaria en la Representación de Intereses', in Angela González and Maria del Pino Ruiz (eds), Democracia Paritária (Aportaciones para un Debate), Barcelona: Alertes, SA

Phillips, Anne (1996) '¿Deben las Feministas Abandonar la Democracia Liberal?' ['Should Feminists Abandon Liberal Democracy?'], in Carmen Castells (ed.), Perspectivas Feministas en Teoría Política [Feminist Perspectives on Political Theory], Barcelona: Paidós 